\author{
Anna Owczarczyk \\ Siedlce University of Natural Sciences and Humanities
}

\title{
IMPACT OF PENSION SYSTEM REFORMS ON PUBLIC FINANCE EXPENDITURES IN POLAND
}

The social security system in each country, if it exists, plays a crucial role in supporting citizens and specific expenditures of the public finance system. Its importance in public spending depends on many factors; in particular, on its source and on its form of financing benefits or pensions. The social security system in Poland is composed of a social insurance and welfare system, a health insurance system, unemployment and family benefits, from which are enumerated an old-age pension, invalidity pension, sickness and maternity insurance, insurance against accidents at work and occupational diseases, and health insurance. The Polish social security system often changes due to implementation of improvements or limits on public spending. The most famous reform took place in 1999 and introduced the largest number of changes in the sphere of pension security. Because the scale of public funds that are passed on to the social security system is very large, pension reforms should are crucial for improving the state of public finances.

The aim of the paper is to present changes that took place in the Polish pension system between 1999 and 2017 and how those changes influenced the amount of public expenditures. The study reviews the research hypothesis: frequent changes in the pension system have a negative impact on the state of Polish public finance. The study covers the years 1999-2017, as well as the previous four years before the implementation of the pension reform. Basic research materials used to conduct the research analysis were reports on implementation of the state budget, data prepared by the Social Insurance Institution and the Agricultural Social Insurance Fund as well as statistical data obtained from the Central Statistical Office.

Key words: social security system, reform, public finance, Poland

JEL Codes: H55

\section{Introduction}

The social security system in each country, if it exists, plays a crucial role in supporting citizens and specific expenditures of the public finance system. Its importance in public spending depends on many factors, in particular, on its source and on its form of financing benefits or pensions.

The social security system in Poland is composed of a social insurance and welfare system, a health insurance system, unemployment and family benefits, from which are enumerated an old-age pension, invalidity pension, sickness and maternity insurance, insurance against accidents at work and occupational diseases, and health insurance ${ }^{1}$. The above-mentioned elements make up the social security system whose point is to guarantee social security. The national government organizes this system into

\footnotetext{
${ }^{1}$ Your Social Security rights in Poland, European Commission 2013 online, available at: http://ec.europa.eu/employment social/empl_portal/SSRinEU/Your\%20social\%20security\%20rights\%20in\%2 0Poland_en.pdf (14.07.2018)
} 
specialized institutions that perform specific tasks in their area of expertise. The key purpose of creating a social security system was to create security against all kinds of social risk, such as loss of a job, the added costs of parenthood, or death of the breadwinner.

The Polish social security system often changes, due to implementation of improvements or limits on public spending. The most famous reform took place in 1999 and introduced the largest number of changes in the sphere of pension security. Because the scale of public funds that are passed on to the social security system is very large, pension reforms are crucial for improving the state of public finances.

In 1999, the social insurance pay-as-you-go system was replaced by a notional defined contribution (NDC) system. Insured persons born before January 1, 1949, were still covered under the social insurance pay-as-you-go system. Insured persons born from January 1, 1949, to December 31, 1968, could choose the new NDC system only or the NDC and individual account system for old-age benefits. Until December 31, 2013, membership in the individual account system was mandatory for insured persons born after December 31, 1968. As of February 1, 2014, membership in the individual account system is voluntary for all insured persons ${ }^{2}$.

The aim of the paper is to present changes that took place in the Polish pension system between the years of 1999 and 2017 and how those changes influenced the condition of public finances. In the study, there will be a review of the research hypothesis that frequently occurring changes in the pension system have a negative impact on the state of Polish public finance. The paper should answer the questions below:

1) How often is the social security system subject to change and what changes does it concern?

2) What was the state expenditure on the Social Insurance Fund (FUS)?

3) What was the direction of state expenditure after introducing changes to the social security system?

4) In what dimension did the pension reform influence the financial condition of the social security system, and the state of public finance?

The study covered the years 1999-2017, and the basic research materials that were used to conduct research analysis were reports on the implementation of the state budget, data prepared by the Social Insurance Institution (ZUS), as well as statistical data obtained from the Central Statistical Office. Some analysis was made by MA Magdalena Gromek in an unpublished thesis "Changes in the social insurance system and their influence on the management of public finance" ("Zmiany w systemie ubezpieczeń społecznych i ich wpływ na zarządzanie finansami publicznymi" [Siedlce University of Natural Sciences and Humanities, under direction od dr Anna Świrska].)

\section{Research results and discussion}

Social security systems appeared in Europe in the $19^{\text {th }}$ century. Up until that time, different institutions and organizations took care of citizens among which can be

${ }^{2}$ online, available at: https://www.ssa.gov/policy/docs/progdesc/ssptw/2016-2017/europe/poland.pdf (access: 14.07.2018 
enumerated for example, communes, gilds, and churches ${ }^{3}$. Currently, almost each state and society has its own regulations and (mostly) public organization which delivers social security to citizens. The social security system is a major pillar of the modern economy. Its role is to satisfy the basic needs of the members of a society and guarantee some standards of living. Due to economic and social changes such as aging of societies, changes in the economy (maintaining high unemployment and small GDP growth), changes in society and politics, growing individualism, changes in family life, and a growing mobility of employees and employers, the social security system needs reforms and adjustments to the current economy ${ }^{4}$.

The most discussable part of the social security system is the part concerning pension insurance. It consists of putting aside financial surpluses that appear during the period of intense work for such a time when there are generally financial shortages, more specifically for the period of old age. The purpose of this insurance is to provide people who are retired the standard of living similar to that which they achieved during their period of professional activity. In Europe, which is the precursor of this type of security, there are different functioning models of pension systems. In most EU countries, the core of the pension system is based on the statutory earnings related to old-age pension schemes. The public pension system often provides also a minimum-guaranteed pension to those who do not qualify for the earnings-related scheme or have accrued only a small earnings-related pension. Minimum guarantee pensions are usually means-tested and are provided either by a specific minimum pension scheme or through a general social assistance scheme. For example, in Denmark, the Netherlands and Ireland, the public pension system provides in the first instance a flat-rate pension, which can be supplemented by earnings related to private occupational pension schemes ${ }^{5}$.

There can be enumerated three types of financing pension security systems:

- Pay-as-you-go,

- Private (capital),

- Combination of pay-as-you-go and private.

Nearly all Western European countries have implemented the system called pay-asyou-go (PAYG) based on compulsory insurance, which is an intergenerational agreement. Benefits are paid out of contributions from current workers who, after reaching retirement age, will receive money from the next generation. In most countries, minimum guarantee pensions are covered by general taxes. Earnings-related schemes are often subsidized by the state budget.

Occupational and private pension schemes are introduced as well. Here, the future pension benefits can be related either to the salary and career length (defined-benefit system) or to paid contributions (defined-contribution system) ${ }^{6}$.

\footnotetext{
${ }^{3}$ Adamiak S., Chojnacka E., Walczak D., Social Security in Poland - Cultural, Historical and Economical Issue. Copernican Journal of Finance \& Accounting. volume 2. issue 2, 2013, p.12

${ }^{4}$ Grzebieniak A., Polski system ubezpieczeń społecznych - zalety i wady, Studia Gdańskie, t. IV, 2007, online, available at: http://www.studiagdanskie.gwsh.gda.pl/pdfy/studia4-7.pdf (access: 14.07.2018)

5 online, available at: http://ec.europa.eu/economy_finance/publications/pages/publication16034_en.pdf (access: 14.07.2018)

${ }^{6}$ online, available at: http://ec.europa.eu/economy_finance/publications/pages/publication 16034_en.pdf (access: 14.07.2018)
} 
The Polish pension system is a kind of combination of both PAYG and private, and its basic postulation is presented below.

The Polish PAYG system is strictly connected with public institutions responsible for the social security system, i.e. the Social Insurance Institution (ZUS) and the Agricultural Social Insurance Fund (KRUS which services farmers). The system functions correctly when the number of insured who pay contributions is significantly greater than the number of beneficiaries. When contributions are insufficient to pay benefits, the deficient amount is supplemented by subsidies from the state budget, thus it affects the amount of state expenditures. Due to the fact that the pay-as-you-go system is "sensitive" to demographic problems, and due to the increasing amounts that are transferred from the state budget to the system every year, changes and reforms are implemented. The basic purpose of these changes is to reduce the growth rate of amounts coming from the state budget.

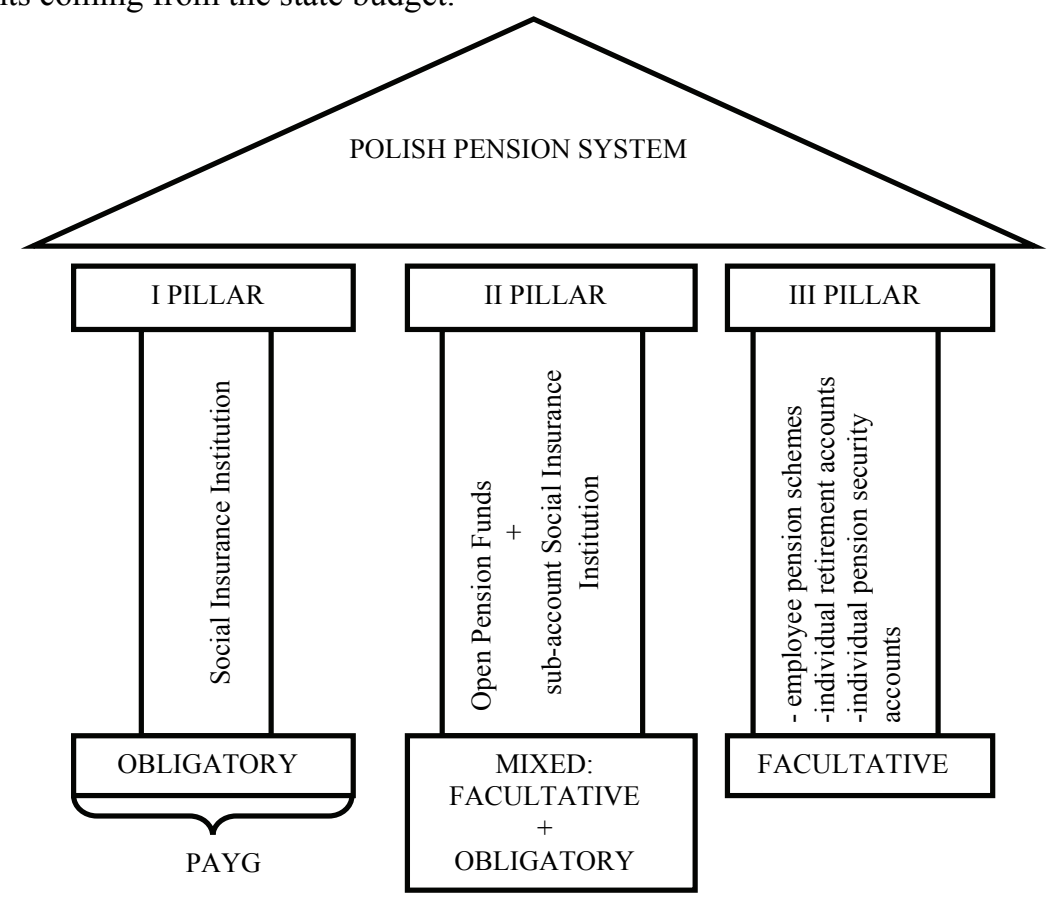

Figure 1. Current Polish pension system

Source: https://emerytura.pzu.pl/abc-emerytury (access: 14.07.2018).

The private system is related to both the second and third pillar. It consists of the fact that paid contributions are not earmarked for the current pensioners, but are invested and serve to finance future benefits for the insured who paid them. In the capital system, the employee throughout his professional activity postpones contributions that are invested in interest-bearing bank accounts. After retirement, the employee may have all capital together with interest or only monthly benefits from interest on capital, paid out for life. After death, capital may be inherited by the employee's family. As can be seen in 
the chart, there is also some PAYG element to the second pillar. Although the employee decides on an Open Pension Fund (OFE), he is still obligated to transfer some contributions to the Social Insurance Institution. This is why the Polish pension system is often described as a mixed system.

The scale of public funds transferred from the state budget to the Insurance Institution is relatively significant if we compare the public expenditures to the deficit. Therefore, any changes introduced to the rules regarding the functioning of social insurance, to some extent are reflected in the amount of state expenditure, and sometimes in the size of the deficit or public debt.

The pension system had become a serious social and economic problem even before the political transformation. The legal act regulating pensions, passed in December 1982, was changed during the years 1983-1989 up to twelve times. Those changes were implemented by a trial and error method: increasing old pensions and later - newer ones, and everything depended on what effects the previous changes brought. These changes in the pension system carried out in the 1980's led to huge chaos: there were no proportions of benefits granted in different periods ${ }^{7}$.

The regulations of the pension security system that were in force until 1998 were subject to constant criticism. It was believed that this system was unfair and expensive. It was predicted that after a dozen or so years a financial collapse would occur. According to available sources, it can be concluded that one of the main disadvantages of the previous system was a number of incentives for early retirement and pension privileges for various professional groups.

In order to repair the social insurance system in force at that time, the Act of 13 October 1998 on the social insurance system and the Act of 17 December 1998 on pensions and disability benefits from the Social Insurance Fund were implemented. Thanks to these laws, on January 1, 1999, one of the most important reforms of the social insurance system in Poland took place. However, not all citizens and politicians were enthusiastic about the changes introduced by the reform. The biggest fear was how the introduced reform would affect the state budget, even though one of its tasks was to improve the state's financial situation. The so-called pension reform introduced by the government of Prime Minister Jerzy Buzek consisted of the fact that the existing pay-asyou-go system was replaced by a new mixed-capital pay-as-you-go system. In order to introduce the new system, universal pension companies were established to manage open pension funds. However, the changes introduced in 1999 did not take into account all citizens. Persons who in the year of the reform's implementation had not yet reached 30 years of age had to submit to the new system, which in turn was associated with obligatory access to pension funds. A second group of citizens between 30 and 50 years of age could choose whether to join the new system or whether they would prefer to remain in the old social security system. The last group of people, aged over 50, had no choice but to remain in the old system. The year 1999 was the beginning of the evolution that took place in the pension security system in the following years. Table 1 contains a summary of all significant changes that were introduced in years 1999-2017.

\footnotetext{
${ }^{7}$ Wiktorow A. Polski system emerytalny po zmianie ustrojowej (1989-2014) Ubezpieczenia społeczne. Teoria i praktyka. Nr 6 (123) ZUS Warszawa 2014, pp. 4-12
} 
All shown in Table 1, changes were introduced in order to improve the functioning of the current social security system, as well as to improve public finances and the financial condition of the Polish pension system; however, as statistics reveal, the effectiveness of these changes is not satisfactory. Regarding the social security system as an element of the public finance system, it is the largest expense item of the state budget each year, nearly $22 \%$ of total expenditures. All these expenses are subsidies to cover the deficit in ZUS and KRUS, and subsidies to cover pensions of soldiers, judges, prosecutors and police officers who are not in the general pension system (about 20 billion PLN) ${ }^{8}$.

Table 1. Changes in the Polish pension system (1999-2017)

\begin{tabular}{|c|c|c|}
\hline Year & Change & Description \\
\hline 1999 & $\begin{array}{l}\text { Social security } \\
\text { system reform }\end{array}$ & $\begin{array}{l}\text { This marks the beginning of the evolution of the entire social security } \\
\text { system. The current system was transformed and four funds were separated } \\
\text { out within it: pension, sickness, disability benefit and accident insurance. } \\
\text { The entire pension system was divided into a pay-as-you-go system and a } \\
\text { capital system. Established Open Pension Funds (OFE) were managed by } \\
\text { the Universal Pension Society (PTE). With the creation of the OFE, part of } \\
\text { the pension contribution was transferred to the Universal Pension Society } \\
\text { account. The reform also introduced provisions on the functioning of } \\
\text { employee pension programs. }\end{array}$ \\
\hline 2000 & $\begin{array}{l}\text { Attempt to increase } \\
\text { the attractiveness of } \\
\text { employee pension } \\
\text { programs }\end{array}$ & $\begin{array}{l}\text { Due to the Act of March 2, } 2000 \text { amending the Act on Employee Pension } \\
\text { Programs and certain other acts, financing of the basic contribution was } \\
\text { changed; previously it was paid from the employee's salary, but since } 2000 \\
\text { it began to be financed by the employer. }\end{array}$ \\
\hline 2003 & $\begin{array}{l}\text { Changes regarding } \\
\text { uniform services }\end{array}$ & $\begin{array}{l}\text { Uniform services were excluded from the general system and returned to } \\
\text { the supply system. }\end{array}$ \\
\hline 2004 & $\begin{array}{l}\text { Changes in OPF } \\
\text { functioning }\end{array}$ & $\begin{array}{l}\text { The Act of August 27, } 2003 \text { amending the Act on the Organization and } \\
\text { Operation of Pension Funds and certain other acts initiated a number of } \\
\text { changes, such as changes in provisions concerning fees, the possibility of } \\
\text { differentiation of fees due to the membership period being annulled or } \\
\text { expired. Another change concerned the benefits collected by PTE on OFE } \\
\text { assets. The act on individual retirement accounts also became applicable. } \\
\text { The implementation of this law aimed to increase incentives for voluntary } \\
\text { savings. }\end{array}$ \\
\hline 2005 & Benefits for miners & $\begin{array}{l}\text { Introduction of privileges for miners: they pay contributions as a society } \\
\text { within the general system; however, their pension is not linked to the } \\
\text { amount of contributions. }\end{array}$ \\
\hline 2009 & $\begin{array}{l}\text { Creation of } \\
\text { "bridging" pensions }\end{array}$ & $\begin{array}{l}\text { It allowed for paying a pension to people working in special conditions that } \\
\text { end their professional activity before reaching the effective retirement age. }\end{array}$ \\
\hline 2011 & $\begin{array}{l}\text { Changes regarding } \\
\text { OFE }\end{array}$ & Lowering the amount of premiums to OFE from $7.3 \%$ to $2.3 \%$. \\
\hline 2012 & $\begin{array}{l}\text { Changes in } \\
\text { retirement age }\end{array}$ & $\begin{array}{l}\text { Starting from January } 2013 \text {, the retirement age was planned to be } \\
\text { systematically increased by } 1 \text { month for every } 4 \text { months until the age of } 67 \\
\text { for both women and men was reached. }\end{array}$ \\
\hline 2014 & $\begin{array}{l}\text { Further changes } \\
\text { regarding OFE }\end{array}$ & $\begin{array}{l}\text { Transferring } 51.5 \% \text { of OFE assets to a sub-account in ZUS (sub-accounts } \\
\text { were introduced in May 2011), changes in the investment profile of OFE, } \\
\text { liquidation of the minimum rate of return and reducing fees. }\end{array}$ \\
\hline 2017 & $\begin{array}{l}\text { Changes in the } \\
\text { general pension } \\
\text { system }\end{array}$ & $\begin{array}{l}\text { Retirement age was lowered for women to } 60 \text {, for men to } 65 \text {. } \\
\text { Changes in the amount of pensions: raising the minimum pension amount } \\
\text { and valorizations. }\end{array}$ \\
\hline
\end{tabular}

Source: Author's own study on the basis of M. Gromek thesis and available Internet sources.

${ }^{8}$ online, available at: http://www.rp.pl/Budzet-i-Podatki/301139902-Budzet-2017-Co-piata-zlotowke-budzetwyda-na-doplaty-do-emerytur.html (access: 14.07.2018) 
In order to analyse the influence of pension system reforms on state expenditures, it is worth presenting transfers from the state budget to the Social Insurance Fund (FUS), which is the state special purpose fund established on 1 January 1999. The Fund is administered by the Social Insurance Institution. Incomes of the Social Insurance Fund come from ${ }^{9}$ :

- social insurance contributions not subject to transfer to Open Pension Funds,

- funds compensating contribution amounts transferred to Open Pension Funds,

- payments from the State Budget and other institutions, intended for benefits that ZUS has been commissioned to pay, with the exception of benefits financed under other budgetary chapters and payments from foreign institutions,

- interest on the FUS bank account,

- a state budget subsidy,

- resources of the Demographic Reserve Fund,

- payments from Open Pension Funds as a result of the insured person reaching an age lower by 10 years than the statutory retirement age.

The FUS budget is in permanent deficit, regarding the difference between the amount of social insurance contributions and the total expenditures of this institution. Thus, the state budget subsidy can be treated as a "lifebuoy". On the one hand, it is additional income of FUS, but on the other - it is a great expenditure of the state budget; thus it should be analysed both as an aspect of FUS budget and an element of state budget.

Table 2 allows for an analysis of the budget of the Social Insurance Fund and the role of the subsidy in the financial condition of this institution.

During the years 1999 to 2017, the amount of collected contributions was not high enough to cover all FUS expenses. The sufficiency of social insurance contributions ranges from $68-79 \%$. Each year finished with a high deficit, which in a free market economy would lead to bankruptcy of the enterprise. Due to the element of state interventionism and subsidy transferred to the FUS account, the FUS deficit could be reduced. Four times (in 2004, 2006, 2007, and 2017) even a surplus was noticeable. A very high surplus in 2017 was caused not only by a high subsidy from the state budget, but also by a cancelling of the nearly 39.15 billion PLN loan which the state budget gave to the Social Insurance Fund in 2009-2014.

The data presented above in Table 2 show that the FUS financial condition was not positive and it was characterized by a deficit in almost every year throughout the analysed period. Although the amounts of subsidy from the state budget fluctuated, it showed an upward tendency in general. Despite high subsidies from the state budget, the Social Insurance Fund was unable to cover all current expenses.

The main reforms introduced during the years $1999-2017$ did not positively affect the financial situation of the Social Insurance Fund.

\footnotetext{
${ }^{9}$ Online, available at: Social Security in Poland 2016.pdf https://www.zus.pl/documents/10182/167615/Social+Security+in+Poland/71ffe1b1-c142-48fa-a67b0c7e1cec6eb6 (access: 14.07.2018)
} 
Table 2. Finance of Social Insurance Fund (mln PLN, 1999-2017)

\begin{tabular}{|c|c|c|c|c|c|c|}
\hline \multirow[b]{2}{*}{ Year } & \multicolumn{3}{|c|}{ Incomes } & \multirow{2}{*}{$\begin{array}{c}\text { Total } \\
\text { expenditures }\end{array}$} & \multirow[t]{2}{*}{ Deficit } & \multirow[t]{2}{*}{ Deficit } \\
\hline & $\begin{array}{c}\text { Incomes from } \\
\text { social insurance } \\
\text { contributions }\end{array}$ & $\begin{array}{c}\text { Subsidy } \\
\text { from the } \\
\text { state } \\
\text { budget }\end{array}$ & Total incomes & & & \\
\hline & $\mathbf{A}$ & B & $\mathrm{C}: \mathrm{A}+\mathrm{B}+$ other & D & A-D & C-D \\
\hline 1999 & 63726.30 & 9459.00 & 73707.80 & 80375.70 & -16649.40 & -6667.90 \\
\hline 2000 & 65051.30 & 15366.0 & 80967.50 & 85684.00 & -20632.70 & -4716.50 \\
\hline 2001 & 69655.70 & 21157.0 & 91563.70 & 96150.50 & -26494.80 & -4586.80 \\
\hline 2002 & 67751.40 & 26987.9 & 95427.70 & 98834.20 & -31082.80 & -3406.50 \\
\hline 2003 & 69725.80 & 28265.3 & 98599.80 & 102207.40 & -32481.60 & -3607.60 \\
\hline 2004 & 73392.60 & 22959.2 & 107713.30 & 107567.70 & -34175.10 & 145.60 \\
\hline 2005 & 77426.20 & 20112.1 & 110980.80 & 111075.50 & -33649.30 & -94.70 \\
\hline 2006 & 80547.00 & 24483.4 & 120859.10 & 119233.00 & -38686.00 & 1626.10 \\
\hline 2007 & 88397.90 & 23893.0 & 129628.10 & 121374.80 & -32976.90 & 8253.30 \\
\hline 2008 & 81646.70 & 33230.0 & 136096.50 & 136133.40 & -54486.70 & -36.90 \\
\hline 2009 & 85300.20 & 30503.3 & 140471.00 & 153437.70 & -68137.50 & -12966.70 \\
\hline 2010 & 88961.70 & 38111.70 & 167480.80 & 170844.70 & -81883.00 & -3363.90 \\
\hline 2011 & 101520.20 & 37513.4 & 162035.80 & 167785.90 & -66265.70 & -5750.10 \\
\hline 2012 & 120421.80 & 39520.8 & 171992.90 & 176439.90 & -56018.10 & -4447.00 \\
\hline 2013 & 121392.40 & 37113.9 & 173529.20 & 183785.80 & -62393.40 & -10256.60 \\
\hline 2014 & 131129.30 & 30362.8 & 186587.20 & 195014.20 & -63884.90 & -8427.00 \\
\hline 2015 & 143095.90 & 42065.7 & 196114.80 & 201717.40 & -58621.50 & -5602.60 \\
\hline 2016 & 151837.30 & 44847,8 & 204681.20 & 208075.00 & -56237.70 & -3393.80 \\
\hline 2017 & 166547.90 & 40978.7 & 260715.60 & 212943.00 & -46395.10 & 47772.60 \\
\hline
\end{tabular}

Source: on the basis of: http://bip.zus.pl/finanse-zus-i-fus/sprawozdania-roczne/sprawozdania-z-wykonaniaplanu-finansowego-zus, access: 14.07.2018

Online, available

http://www.zus.pl/documents/10182/167642/Rocznik+stat+system+pozarolniczy+1999+2002/d36c56e4-94e34bd2-a643-7c29b831de1f access: 14.07.2018 and M. Gromek thesis

The FUS subsidy is at the same time an expense of the state budget and influences the condition of the public finance system in Poland. Table 3 presents the FUS's subsidy as a transfer from the state budget.

Analyzing the above research, subsidies to the Social Insurance Fund account, as well as the total spending of the country, are becoming higher each year. Since the introduction of pension reform in 1999, total state expenditure has more than doubled, and state subsidies for the Social Security Fund have more than quadrupled. Although the amounts of subsidies are fluctuating, they are characterized by an upward trend. It can be stated that to a certain extent, the increasing amounts of subsidies allocated to the Social Insurance Fund have a negative impact on the general state of public finances, because if the subsidies increase, then the state's expenses also do so.

Reforms introduced in the years 1999-2017 have not brought satisfactory results. Their effects are short-lived and can be limited to up to one year. The changes introduced in 2014 in no way solved the problems of the Social Insurance Fund and did not reduce the demand for subsidies from the state budget. In 2017, although the share of 
public subsidies decreased, it should be recalled that the budget "lost" the amount of 40 mln PLN, because it redeemed the FUS loan.

Summing up, all changes introduced in the functioning of the entire social security system result in ever-increasing financial requirements on the system, which in turn have a negative impact on the overall state of public finances.

Table 3. The share of transferred subsidy in total state expenditures (1999-2017)

\begin{tabular}{|c|c|c|c|}
\hline Year & Subsidy from the state & State expenditures & Share \\
\hline & mIn PLN & bln PLN & \% \\
\hline $\mathbf{1 9 9 9}$ & 9459.0 & 138401.2 & 6.8 \\
\hline $\mathbf{2 0 0 0}$ & 15366.0 & 151054.9 & 10.2 \\
\hline $\mathbf{2 0 0 1}$ & 21157.0 & 172885.2 & 12.2 \\
\hline $\mathbf{2 0 0 2}$ & 26987.9 & 182922.4 & 14.8 \\
\hline $\mathbf{2 0 0 3}$ & 28265.3 & 189153.6 & 14.9 \\
\hline $\mathbf{2 0 0 4}$ & 22959.2 & 197698.3 & 11.6 \\
\hline $\mathbf{2 0 0 5}$ & 20112.1 & 208132.9 & 9.7 \\
\hline $\mathbf{2 0 0 6}$ & 24483.4 & 222702.9 & 10.9 \\
\hline $\mathbf{2 0 0 7}$ & 23893.0 & 252323.9 & 9.5 \\
\hline $\mathbf{2 0 0 8}$ & 33230.0 & 277893.5 & 11.9 \\
\hline $\mathbf{2 0 0 9}$ & 30503.3 & 298028.5 & 6.9 \\
\hline $\mathbf{2 0 1 0}$ & 38111.7 & 294893.9 & 12.9 \\
\hline $\mathbf{2 0 1 1}$ & 37513.4 & 302681.6 & 12.4 \\
\hline $\mathbf{2 0 1 2}$ & 39520.8 & 318001.9 & 12.4 \\
\hline $\mathbf{2 0 1 3}$ & 37113.9 & 321345.3 & 11.5 \\
\hline $\mathbf{2 0 1 4}$ & 30362.8 & 312519.5 & 9.7 \\
\hline $\mathbf{2 0 1 5}$ & 42065.7 & 331743.4 & 12.7 \\
\hline $\mathbf{2 0 1 6}$ & 44847.8 & 360843.1 & 12.4 \\
\hline $\mathbf{2 0 1 7}$ & 40978.7 & 375768.5 & 10.9 \\
\hline
\end{tabular}

Source: Author's own study on the basis of https:/www.mf.gov.pl/ministerstwo-finansow/dzialalnosc/finansepubliczne/budzet-panstwa/wykonanie-budzetu-panstwa and http://bip.zus.pl/finanse-zus-i-fus/sprawozdaniaroczne/sprawozdania-z-wykonania-planu-finansowego-zus, access: 14.07.2018

http://www.zus.pl/documents/10182/167642/Rocznik+stat+system+pozarolniczy+1999+2002/d36c56e4-94e34bd2-a643-7c29b831de1f access: 14.07.2018 and M.Gromek thesis

\section{Conclusions and implications}

The Polish social security system underwent a great transformation in 1999. The key change that resulted from the reform was replacing the system with a defined benefit with a defined contribution system in the first pillar and applying the principle of a defined contribution also in the second pillar of the new system ${ }^{10}$. Since the implementation of the above-mentioned reform, numerous changes have been made to the pension system which were aimed at improving the financial status of the social insurance and public finance spending. Unfortunately, changes introduced to improve

${ }^{10}$ L. Oręziak, OFE katastrofa prywatyzacji emerytur w Polsce. Instytut Wydawniczy Książka i Prasa, Warszawa, 2014, p. 200 
the current situation have not always been positively reflected in the finances of the social security system and the state budget.

On the basis of the conducted research it can be said that:

- frequently introduced changes have not positively impacted the condition of state expenditures, as the subsidies for the Social Insurance Fund and the total spending of the country are becoming higher each year in the analysed period; the consequence of such an allocation of public finance is the still increasing budget deficit.

- change in the year 2017 seems to be a merely political answer for the reform of 2012 and may cause a considerable growth in state expenses in the near future,

- such frequent changes cause confusion within society and may raise problems with the calculation of future pension for current employees,

- the character of introduced reforms (especially those of 1999, 2011, 2014) demands careful data collection of the contributions paid to ZUS, the OFE, or to both ZUS and the OFE. What is more, such frequent changes demand employees keep up with all legal acts that refer to the social security system in order to be aware of a proper calculation of their pensions. That is time consuming and makes unnecessary activity for ordinary people.

\section{References}

Adamiak S., Chojnacka E., Walczak D., Social Security in Poland - Cultural, Historical and Economical Issue. Copernican Journal of Finance \& Accounting. volume 2. issue 2, 2013

Gromek M., Zmiany w systemie ubezpieczeń społecznych i ich wpływ na zarządzanie finansami publicznymi, unpublished master thesis 2017, under direction: dr Anna Świrska, Siedlce University of Natural Sciences and Humanities

Grzebieniak A., Polski system ubezpieczeń społecznych - zalety i wady, Studia Gdańskie, t. IV, 2007, online, available at: http://www.studiagdanskie.gwsh.gda.pl/pdfy/studia4-7.pdf

Oręziak L. OFE katastrofa prywatyzacji emerytur w Polsce. Instytut Wydawniczy Książka i Prasa, Warszawa, 2014

Social Security in Poland.pdf 2016

Your Social Security rights in Poland, European Commission. (2013). online, available at: http://ec.europa.eu/employment_social/empl_portal/SSRinEU/Your\%20social\%20security\%20rig hts\%20in\%20Poland_en.pdf) (access: 14.07.2018)

Wiktorow A. Polski system emerytalny po zmianie ustrojowej (1989-2014) Ubezpieczenia społeczne. Teoria i praktyka. Nr 6 (123) ZUS Warszawa 2014

Web pages:

https://www.mf.gov.pl/ministerstwo-finansow/dzialalnosc/finanse-publiczne/budzetpanstwa/wykonanie-budzetu-panstwa (access: 14.07.2018)

http://bip.zus.pl/finanse-zus-i-fus/sprawozdania-roczne/sprawozdania-z-wykonania-planufinansowego-zus (access: 14.07.2018)

http://www.zus.pl/documents/10182/167642/Rocznik+stat+system+pozarolniczy+1999+2002/d36 c56e4-94e3-4bd2-a643-7c29b831de1f (access: 14.07.2018)

http://bip.zus.pl/finanse-zus-i-fus/sprawozdania-roczne/sprawozdania-z-wykonania-planufinansowego-zus,

http://www.zus.pl/documents/10182/167642/Rocznik+stat+system+pozarolniczy+1999+2002/d36 c56e4-94e3-4bd2-a643-7c29b831de1f (access: 14.07.2018)

http://www.rp.pl/Budzet-i-Podatki/301139902-Budzet-2017-Co-piata-zlotowke-budzet-wyda-nadoplaty-do-emerytur.html (access: 14.07.2018) 
http://ec.europa.eu/economy_finance/publications/pages/publication16034_en.pdf (access: 14.07.2018)

https://www.ssa.gov/policy/docs/progdesc/ssptw/2016-2017/europe/poland.pdf (access:

14.07.2018)

\section{Streszczenie}

System zabezpieczenia społecznego w każdym kraju, jeśli istnieje, odgrywa kluczową role we wspieraniu obywateli, jednocześnie stanowi duże obciążenie finansowe dla wydatków budżetowych państwa. W Polsce składa się on z systemu ubezpieczeń społecznych i opieki społecznej, systemu ubezpieczeń zdrowotnych, zasiłków dla bezrobotnych i świadczeń rodzinnych, z których wyliczono emeryturę, rentę inwalidzką, ubezpieczenie chorobowe i macierzyńskie, ubezpieczenie od wypadków przy pracy i choroby zawodowe i ubezpieczenie zdrowotne.

Celem artykułu jest przedstawienie zmian, jakie zaszły w polskim systemie emerytalnym w latach 1999-2017 oraz wpływu tych zmian na wysokość wydatków publicznych. W badaniu dokonano weryfikacji hipotezy badawczej: często występujące zmiany w systemie emerytalnym mają negatywny wpływ na stan polskich finansów publicznych.

Badaniem objęto lata 1999-2017. Podstawowymi materiałami badawczymi wykorzystanymi do przeprowadzenia analizy badań były sprawozdania $\mathrm{z}$ realizacji budżetu państwa, dane przygotowane przez Zakład Ubezpieczeń Społecznych oraz dane statystyczne uzyskane z Głównego Urzędu Statystycznego.

Słowa kluczowe: System zabezpieczenia społecznego, Reforma, Finanse publiczne JEL Codes: H55

Information about author:

\section{Dr Anna Świrska}

Siedlce University of Natural Sciences and Humanities

Faculty of Economic and Legal Sciences

U1. Żytnia17/19

08-110 Siedlce

e-mail: anna.swirska@uph.edu.pl

ORCID: 0000-0003-1363-2296 